\title{
Legitimacy and Policy during Crises: Subnational COVID-19 Responses in Bolivia
}

\author{
V. Ximena Velasco-Guachalla, Calla Hummel, Jami Nelson-Nuñez and Carew Boulding
}

\begin{abstract}
Why did some Bolivian departments have more success containing COVID-19 than others? We argue that low government legitimacy hampers coordinated responses to national crises, particularly where political polarization is severe and the crisis response becomes politicized. Low legitimacy can intensify the challenges of poverty and poor infrastructure. An original dataset of daily observations on subnational coronavirus policy and cell phone mobility data, paired with administrative data on cases and deaths, suggests that political divisions influenced governors' policy implementation and citizens' compliance. In departments that opposed the president, policies were more likely to deviate from the stricter national policy while mobility and protest activity were high. In departments aligned with the president, local policy followed national policy and citizens complied with policy and quarantine restrictions for a longer period of time.
\end{abstract}

$T$ 2020 novel coronavirus pandemic arrived at a time of heightened political turmoil in many countries. The United States, Brazil, Mexico, and Bolivia were already deep in political crises around corruption, polarization, legitimacy of government, and worries about democratic backsliding when the pandemic began spreading globally in early 2020. These crises shaped

Data replication sets are available in Harvard Dataverse at: https://doi.org/10.7910/DVN/W8LTRL

A list of permanent links to Supplemental Materials provided by the authors precedes the References section.

V. Ximena Velasco Guachalla (1) is Assistant Professor of Political Science at the University of Essex(vv20291@essex. ac.uk).

Calla Hummel 1 is Assistant Professor of Political Science at the University of Miami (chummel@miami.edu).

Jami Nelson-Nuñez (1) is Assistant Professor of Political Science at the University of New Mexico (jaminunez@unm. edu).

Carew Boulding (1) is Associate Professor of Political Science at the University of Colorado Boulder (carew.boulding@ colorado.edu). governments' and citizens' responses to the pandemic (Cornelson and Miloucheva 2020; Patel et al. 2020). In this paper, we explore how polarizing political crises affected the successes and failures of pandemic policy responses at the sub-national level in Bolivia.

In Bolivia, the virus spread unevenly across the country, hitting some places and populations harder than others. The national government responded swiftly with strict quarantine measures. However, national policy did not contain the pandemic within Bolivia and cases exploded when the national government devolved policy to local governments. After two hundred days, per capita cases and deaths were on par with Brazil and Peru, which were among the worst-hit countries in the Americas, and some Bolivian departments ${ }^{1}$ experienced the highest per capita death rates in the world (Trigo, Kurmanaev, and McCann 2020). Why did some Bolivian departments have more success containing the pandemic than others?

We argue that the recent political crises and polarization over the legitimacy of the government created conditions in Bolivia that hindered a coordinated response and led to different outcomes around the country. Political turmoil around the legitimacy of the government created a crisis of legitimacy at various levels of government and heightened polarization between supporters of the interim government and opponents. We are specifically referring to polarization around legitimacy of the government, where supporters and opponents of the government hold very strong and often permits unrestricted re-use, distribution, and reproduction in any medium, provided the original work is properly cited. 
incompatible views of the legitimacy of the administration itself. Low legitimacy weakened incentives for compliance, cooperation, and coordination in public policy implementation. Politicized compliance and coordination then led to worse outcomes in terms of cases and deaths, and exacerbated pre-existing inequalities.

Bolivia is a case of the politicization of health policy in a political crisis, with important lessons for other democracies in crisis. Similar to the United States and Brazil, its institutions give local governments power to oppose national policy. Again similar to the United States and Brazil, Bolivia experienced rising polarization prior to the pandemic, particularly after a constitutional referendum in 2016. This initial polarization increased dramatically following a political crisis in 2019. During the crisis, the longstanding president, Evo Morales, resigned and the interim president, Jeanine Añez, unleashed police brutality on protesters and prosecuted her political opponents (Anria and Roberts 2019; Lehoucq 2020; Mamani 2020). In this paper we explore how these conditions of polarization and political crisis shaped the Bolivian response to the novel coronavirus and health outcomes.

Our team collected daily data on novel coronavirus policies, cases, deaths, mobility, and protests from Bolivia's nine departments from March through September of 2020. We gathered monthly administrative data on all deaths reported at the departmental level from the Civil Registry Service (SERECI 2020), and The New York Times. We find that when the national government devolved policy to local governments, cases spiked throughout the country but particularly in opposition departments where protests were higher and governors relaxed policies. While inequality in resources and state capacity helped some local governments and hurt others, lack of legitimacy blocked the national government's rushed attempts to set strict quarantine policies. We find that after most subnational governments decided to ease coronavirus restrictions, the two poorest and opposition-controlled departments reported an increase in overall deaths in July that was over seven times their average monthly deaths while the wealthiest department saw overall deaths peak in August at twice the average monthly deaths.

The article proceeds with a background section outlining Bolivia's experience with and response to the novel coronavirus pandemic before elaborating the theoretical ramifications of political crisis, low legitimacy, and politicization of health policy and setting out hypotheses. We then describe our data collection sources, protocols, and methodology. We present the results of our descriptive data analysis, focusing on administrative data, cellphone mobility data, and a subnational policy index developed in conjunction with teams at Oxford University and the Observatory for the Containment of COVID-19 in the Americas at the University of Miami (Hale et al. 2020; Knaul et al. 2020). We paired this data with protest event count data that we collected for all Bolivian departments.
We conclude with implications for developing democracies in crisis.

\section{Background: The Novel Coronavirus in Bolivia}

The Ministry of Health identified Bolivia's first two COVID-19 cases on March 10, 2020. The national government responded swiftly, closing schools, cancelling events and gatherings, imposing a national curfew and travel restrictions within a few days, and then closing Bolivia's borders and ordering a strict national quarantine that started on March 22 (Ministerio de la Presidencia 21 Marzo 2020). The quarantine slowed but did not contain the virus. Santa Cruz's initial cases quickly became dozens and the department experienced community spread by April and a collapsing hospital system in May. Oruro initially appeared to contain its cases but periodic outbreaks reemerged. La Paz and Cochabamba reported their first cases before the quarantine and continued to experience community spread during confinement. Several departments entered quarantine with no cases but reported confirmed COVID-19 cases in the first week: Potosi on March 26, Chuquisaca on March 27, Pando on March 28, and Tarija on March 30. Beni, the exception, reported its first case on April 20 but within two weeks of the first case, the case count reached into the hundreds and the department health system collapsed as health care workers became too sick to staff hospitals and clinics. On May 22, Beni's governor declared a health disaster and emergency in the department due to the rapid spread of the virus (Agencia Boliviana de Información 2020).

Bolivia experienced the arrival of the pandemic in the middle of an ongoing political crisis which set the conditions for the politicization of health policy and an uneven response to the public health crisis (Hummel et al. 2020). Here, we briefly present the background context needed to understand how the pandemic developed in Bolivia, focusing on the political crisis of 2019-2020, the institutional context that allowed for the central government to delegate policy to departments, and the state of the health care system.

\section{Political Crisis}

Bolivia is a landlocked, low-income country of 11 million people with a turbulent political history. Under the administration of Evo Morales, who first won election in 2005 and resigned in 2019, and the Movement towards Socialism (Movimiento al Socialismo or MAS), the Bolivian government oversaw sweeping social programs, sustained economic growth, and substantial reductions in poverty and inequality (Mamani 2020). The administration created a pension system that guarantees monthly cash payments to all Bolivians over 60, expanded cash transfer programs to families, and quintupled the minimum wage (Anria and Niedzwiecki 2016, Niedzwiecki and Anria 
2019). Under the economic policies of the former finance minister and then president Luis Arce, between 2005 and 2018 economic growth averaged nearly 5\% a year, GDP per capita more than tripled, the percentage of Bolivians living in poverty fell from $60 \%$ to $35 \%$ of the population, and inequality declined from a GINI index of 58.5 to 44 (Farthing 2019; World Bank 2020).

While the Morales government oversaw unprecedented economic growth, it was also plagued by corruption scandals and democratic backsliding. The most notorious move towards consolidation of power happened when the Morales administration held a constitutional referendum to abolish term limits in February 2016 and then ignored the unfavorable results (Mamani 2020). Following the October 2019 presidential election, protests broke out around the country over allegations of electoral fraud. Former Morales supporters, trade unions, the police, and the military joined the opposition's calls for Morales to resign and he stepped down on November 10, 2019 (Derpic 2019). Jeanine Añez, a little-known opposition senator and the second vice president of the senate, assumed the presidency. Her ascension to power was met with strong opposition from Morales' supporters and a wave of protests wracked the country after her inauguration. Añez sent police and military into the streets, police opened fire on two largely indigenous protests and by the end of November, thirty-five people had died in the crisis (Chaski Clandestina 2019; Derpic 2020). Añez appointed a disparate collection of opposition figures to her administration. Prior to the pandemic, the interim administration had primarily focused on prosecuting former officials from Morales's MAS party.

\section{Institutional Context}

Bolivia entered the pandemic with a central government that lacked widespread support or legitimacy and political institutions that allowed for a decentralized response. Decentralization reforms swept Latin America in the 1990s (McNulty 2019; O’Neilll 2005) and Bolivia set an early example with its 1994 Law of Popular Participation (Anria 2018; Farthing and Kohl 2014; Madrid 2012; Fauget 2012). The law transferred legislative power and considerable resources to Bolivia's nine departmental and 339 municipal governments. The 1994 decentralization reform has been replicated around the world and hailed as a way to make government more efficient and responsive to local needs (Faguet 2012). This institutional arrangement offered a way for the central government to avoid taking the blame for unpopular pandemic response policies and meant that there was a mechanism to devolve decision-making to local health departments.

Bolivia entered the pandemic with a fragile healthcare system, a struggling education apparatus, and crumbling national infrastructure. All Bolivians are entitled to public healthcare but in practice public hospitals are understaffed, undersupplied, and struggle with corruption (Gray Molina, Rerez de Rado, and Yañez 1999). Few hospitals exist outside of large cities and in March 2020, the entire department of Pando did not have a fully functioning hospital. Prior to the pandemic, Bolivia had only thirtyfive functioning intensive care beds (Escalera-Antezana et al. 2020). While the Morales administration pledged to modernize Bolivia's infrastructure, most of the nation's roads are falling apart, which complicates even the delivery of medical supplies to the existing hospitals and clinics.

Corruption made the situation worse: the interim government announced in March 2020 that it was spending millions to buy 170 ventilators but when the ventilators arrived, they did not meet intensive therapy standards (Kitroeff and Taj 2020). The health minister and others had overcharged the state, accepted kickbacks, and received substandard equipment. The country experienced a wave of protests denouncing corruption, the government's pandemic response, and the lack of personal protective equipment and medical supplies.

Under pressure, the national government delegated much of the containment policy to local governments on June 1, 2020, after which COVID-19 cases exploded across Bolivia. In June and July, a wave of cases forced hospitals to close as their staff were infected and to turn patients away, leading to hundreds of bodies left in the streets and burial services collapsing across the country (Cuevas 2020; Condori R. 2020; Peńaranda 2020). Amid a wave of protests, the national government postponed, for a third time, inperson presidential elections to October 18, announced a post-confinement phase starting September 1, and allowed in-person political campaigns to start on September 6 (Ministerio de la Presidencia 27 Agosto 2020). On September 10 , six months into the pandemic, Bolivia had 124,204 confirmed COVID-19 cases, a 29\% positivity rate, 7,193 confirmed deaths from COVID-19, and 19,000 more deaths than by the same time in 2019 .

\section{Politicized Health Policy and Government Legitimacy in a Crisis}

Structural factors associated with poverty and low government capacity, including health infrastructure, informal sector labor, endemic corruption, and high rates of poverty, explain some of the variation in pandemic outcomes in Bolivia and elsewhere (Hummel et al 2021). We argue, however, that political dynamics are critical to understanding how the pandemic unfolded in Bolivia. All policies, even health policy, can be politicized or bureaucratized to varying degrees. While disasters and crises sometimes represent moments of unity and are put in the hands of experts (Baekkeskov and Rubin 2014), protracted and publicly salient crises can provide opposition actors opportunities to challenge government responses. We argue that crises of legitimacy, such as the one Bolivia was 
experiencing as the pandemic hit, can intensify the politicization of policy responses to a crisis like the COVID-19 pandemic. In the absence of a unifying national response, pandemic policy becomes entangled with partisan divisions, resulting in unequal policies, unequal compliance, and unequal health and mortality outcomes.

We see the crisis of legitimacy of the central government as important in two ways. First, a central government without strong popular or elite support faces high barriers to enacting unpopular policies, even if necessary. Despite the need for a coordinated response (Zoraster 2006), crises of legitimacy increase the likelihood that government actors will politicize decisions around policy responses (Zoraster 2006). Where pre-existing political structures can facilitate dissent, coordination is likely to break down where opposition to the national government is greatest. Recent scholarship suggests that political divisions between local governments and national administrations can obstruct policies initiated by national governments (Fenwick 2016; Niedzwiecki 2016). For example, Niedzwiecki (2018) finds that co-partisan linkages between the national government and regional governors in Brazil facilitated the implementation of the acclaimed Bolsa Familia cash transfer program, while regional leaders of opposition parties in Argentina blocked the implementation of such transfers. Eaton (2017) suggests that ideological differences between presidents and regional leaders can lead to local economic policies that are at odds with national government stances.

Political divisions between local and national governments have recurrently emerged in Bolivia (Eaton 2011; Zegada and Brockmann 2016; Vergara 2018), setting the stage for contention over pandemic policy. For example, Hoey (2017) documents the challenges that healthcare workers faced in implementing the Morales administration's ambitious program to eradicate malnutrition. She finds that political friction arose between the national government's program housed in the Ministry of Health and health centers in departments run by opposition leaders. Coordination and cooperation are crucial for the delivery of key medical supplies and support in crises and decentralized settings can complicate cooperation (Marks and Lebel 2016). Thus, decentralized contexts provide institutional mechanisms through which actors can more easily politicize crisis response. The crisis of legitimacy in Bolivia made it more likely that actors would actually do so.

Second, crises of legitimacy shape citizen compliance with government policy, making it harder for citizens to trust the government's decisions and more likely that people will react dismissively or in opposition. Political legitimacy and trust in government are crucial for voluntary compliance, particularly in a protracted crisis. Levi (1997, 153) argues that "citizens are willing to go along with a policy they do not prefer as long as it is made according to a process they deem legitimate, and they are less willing to comply with a policy they like if the process was problematic." Studies have shown strong relationships between trust, legitimacy, and voluntary compliance (Lopez-Calva 2019; Braithwaite and Levi 1998; Scholtz and Lubell 1998; Putnam, Leonardi, and Nanotti 1993; Hardin 1991). Polarization between groups in society makes compromise, coordination, and cooperation more difficult to achieve across political lines (Sani and Sartori $1983)$, and is a growing problem in many democracies (Carothers and O'Donahue 2019). Studies show that social fragmentation can have dire effects on the distribution and delivery of public goods (Alesina, Baqir, and Easterly 1999) and hinders society's ability to coordinate collective action in a crisis (Cornelson and Miloucheva 2020). More specific to the pandemic, where health policies have been politicized in polarized contexts, citizens are more likely to distrust and resist both government health officials and doctors (Franklin Fowler and Gollust 2015). The combination of a crisis of political legitimacy in conjunction with decentralized institutions can therefore lead to uneven subnational policy and varying levels of citizen compliance along partisan lines.

Our argument and the literature on decentralization, polarization, and legitimacy set out theoretical expectations for how these conditions influenced national and subnational pandemic responses. Where leaders have varying degrees of authority to determine policy, implement or obstruct national policy, galvanize dissent, organize protest and influence citizen behavior, and where citizens hold polarized political views, we expect to see policy responses and citizens' compliance follow the patterns in Table 1.

Table 1

$2 \times 2$ of theoretical expectations for empirical data

\begin{tabular}{lll}
\hline & Opposition Electorate & Pro-Government Electorate \\
\hline Opposition governor & Highest mobility & Moderate mobility \\
& Protest most likely & Moderate policy \\
& Less restrictive policy & Some protest \\
Allied governor & Moderate mobility & Lowest mobility \\
& Strict policy & Strict policy \\
& Some protest & Protest least likely \\
\hline
\end{tabular}


If pandemic policy were shaped by partisan concerns, as we describe here, we expect the patterns laid out in table 1 to appear in our data from Bolivia. Specifically, we expect that governors from parties that are not allied with the president will use their autonomy to make less restrictive policy. We expect opposition voters to defy national policy by protesting and flouting quarantine restrictions. In places where the governor and the majority of voters oppose the president, we expect to see lax policy, many protests, and high mobility as measured by Android cell phone data from Google (Google LLC 2020). Where the governor opposes the president but many voters support the president, we expect that the governor will relax some policies and that opposition voters will protest and move around while others will comply. In places where the governor is allied with the president and a clear majority of voters support the president, we expect to see strict policy from the governor and high compliance from voters. In Bolivia, several departments have opposition governors and electorates. Several more have opposition governors and highly divided voters, where many voters support the opposition, many voters support the president, and the rest are wary of all politicians and parties. Only one department has an allied governor and a clear majority of voters who support the president. No department has an allied governor and an opposition-dominated electorate, but we filled out the $2 \times 2$ for completeness and generalizability.

Note that the outcome we expect in this context is that the opposition will flout the policy of the national government - regardless of left-right ideology. We expect dynamics to be partisan rather than ideological. With the elections that were canceled in 2019 and the political crisis that ensued, voters sorted into partisan MAS and antiMAS blocs (Arequipa Azurduy 2020). Returning to our specific expectations for the data, the Bolivian national government acted quickly with restrictive measures, thus, we expect to see the opposition flout restrictions. In countries where the national government ignored the pandemic, we expect to see the opposition call for, enact, and comply with restrictions. We expect this dynamic to occur regardless of party ideology. We evaluate subnational variation in experiences with the novel coronavirus in Bolivia using original and administrative data. In the following section, we explain how we collected and analyzed the data and then detail the results.

\section{Methodology}

We analyze mobility, protest, and COVID-19 cases and deaths to assess the effect of legitimacy on the pandemic response. Mobility data comes from Android cellphone location data compiled by Google. Mobility is a proxy for citizen compliance with government stay-at-home directives and transportation restrictions: we assert that in places where mobility averages go down and stay low, people comply with restrictions whereas in places where mobility does not decrease or decreases and then increases, people do not comply with restrictions.

Protest data comes from local daily newspaper reports of protests and is a proxy for legitimacy: we assert that where people protest the government in large numbers, they question the legitimacy of the government and its actions. Several departments, including Potosí and Tarija, explicitly banned protest in their initial pandemic decrees, hence protesting is also a clear sign of noncompliance with those departments' pandemic policies. COVID-19 cases and deaths come from national and local departments of health and proxy the abilities and success of the local and national governments in containing the pandemic: where cases and deaths rise, we assert that governments are either unable or unwilling to contain the pandemic, and where cases and deaths decrease or stay steady, governments are able and willing to mitigate the pandemic.

We collected daily national- and departmental-level data on COVID-19 cases, deaths, protests, and public policies to prevent and contain the virus from March 10 to September 25, 2020. We tracked ten policy areas since the first confirmed cases on March 10. The variables and the index that we built are based on the Oxford COVID-19 Government Response Tracker (OxCGRT) 5.0, which measures the government response to the pandemic (Hale et al. 2020; Knaul et al. 2020; Hummel et al. 2020). We track stay-at-home orders, school closings, office closings, suspension of public transportation, mask mandates, event bans, restrictions on gatherings, information campaigns, domestic travel restrictions, and international travel restrictions. All policy variables have a value between 0 and 1 . In coding, we consider whether each measure was in effect each day and we code whether its application was partial or total. Please see the codebook and tables of the variables in the online appendix for more details.

We construct a policy index of these ten variables using Knaul et al. (2020)'s index construction (see the online appendix for the full index construction). Early policy action carries more weight in the index and late policies add smaller values. The index gives every subnational government a daily score between 0 and 100, where 0 means that no policies have ever been in place and 100 signifies that all policies have been in place from the first case.

To collect daily data, we combed the official websites of Bolivia's nine departmental governments, as well as the websites, press releases, and public databases of the Ministry of Health, the Ministry of Communication, the Ministry of Public Works, the National Institute of Statistics, the Bolivian Information Agency, the Civic Register (SERECI), and the official information service for COVID-19, Bolivia Segura (https://www.boliviasegura. gob.bo/). We added information from the Departmental 
Health Service (SEDES) of each department and reports from the independent national and local news media.

The mobility data comes from Android cell phones that use Google location services and the data is compiled by Google. The data covers aggregate changes in mobility across six categories and is available at the provincial, departmental, and national level. We compile the leisure and commercial categories into a daily departmental average and a seven-day running average. Google releases public data online at https://www.google.com/covid19/ mobility/. Note that most Bolivians have a cell phone and many people who do not have a home computer instead buy Android smartphones. A 2018 study on cellphone usage in Bolivia found that individuals are increasingly opting for Android as their preferred operating system over alternatives. The study highlights that only $7.7 \%$ of Samsung Galaxy users switched to Apple while the remaining $92.3 \%$ continued to use smartphones with Android operating systems. Among those who switched their iPhones, $18 \%$ chose Samsung devices instead (Redacción Central Bolivia en Tus Manos 2019). Additionally, we expect that internet connectivity via smartphone has increased in the last year as internet access has become more central to accessing information, education, and social assistance. Between 2015 and 2020, internet access in the country grew significantly and of all internet connections, $91.99 \%$ are established through mobile access technologies (Autoridad de Regulacion y Fiscalizacion de Telecomunicaciones y Transporte 2020).

We verified and triangulated data by checking numbers and codes with team members and with different sources of information. We code public policies using official national, departmental, and municipal decrees and laws. The daily case and death numbers come from the SEDES of each department. We suspect that the official numbers are lower than actual infections because there has been a shortage of tests in Bolivia since March 2020 and the World Health Organization recommends a positivity rate of less than 3\%. In Bolivia, the positivity rate fluctuated between 5\% in March, up to 65\% in July, and dropped to 35\% in September (Our World in Data 2020), suggesting that many cases were not diagnosed. The numbers reported by the SEDES, the Ministry of Health, and independent media are the same, suggesting that the underreporting of confirmed cases is due to the scarcity of tests and not systematic manipulation of the data.

\section{Results}

The intense politicization of health policy across the Bolivian departments contributed directly to the lack of coordination and compliance during the pandemic. Hundreds of anti-government and pro-election protests took place throughout quarantine but so did pro-government and anti-MAS demonstrations (Laserna 2020). Both groups challenged each other using a form of political participation that was in direct violation of lock-down regulations. In this section, we demonstrate that protest activity was highest in places with opposition governors and electorates. We then show that once the national government delegated policy decisions to local governments, opposition governors with opposition electorates relaxed policies the most. We show that cases and deaths spiked across the country after local governments exercised more autonomy in policy implementation. Finally, we demonstrate that the pandemic exacerbated pre-existing inequality, with the poorest departments experiencing the highest increases in deaths.

We use original quantitative data from Bolivia's nine departments and administrative data to make our case. Referring back to the theoretical expectations in table 1 , we classify Bolivia's departments in the $2 \times 2$ in table 2 . We classify the departments based on the party of the governor and vote shares from the 2019 presidential election. The classification indicates ideal-type departments like Cochabamba (opposition electorate and governor) and Tarija (pro-Añez governor and electorate) that fit the classification and the expectations. The $2 \times 2$ also identifies several mixed-case departments, where the governor and electorate are not aligned with each other, and predictably mixed outcomes for mobility, protest, and policy.

The opposition governor and electorate departments generally followed our expectations, as did the allied governors and divided electorates. We have classified electorates as fully opposition or divided, because only Tarija had an electorate that was solidly behind President Añez and her allies. Most electorates are either overwhelmingly in support of former president Morales and the MAS party or are deeply divided. The opposition governor and divided electorate category is mixed, with some departments resembling opposition-opposition departments and others combining characteristics of both categories. For example, the president was from Beni and many voters there supported her but the governor was from the MAS and many voters were staunch MAS supporters. Table 3 summarizes key departmental descriptive statistics on demographics, the economy, and politics.

Protests took place in all departments between March and September 2020, and roughly half of all protest events happened in the opposition departments of Cochabamba, $\mathrm{La} \mathrm{Paz}$ and Oruro (about 48\%). Of all protest events, 24\% took place in Cochabamba, $17 \%$ in La Paz, $17 \%$ in Santa Cruz, 9.9\% in Chuquisaca, and 7\% in Oruro. Protests in Santa Cruz were concentrated in areas with opposition voters. There were two periods of protest with distinct demands: health-related demands dominated protests from March to July, whereas election demands dominated demonstrations throughout August, as table 4 shows.

Protests demanding elections that took place during the first weeks of the Añez administration resurfaced during the first months of quarantine, and continued through the 
Table 2

\section{Bolivian departments classified by governor's and electorates' partisanship}

\begin{tabular}{|c|c|c|}
\hline & Opposition Electorate & Pro-Government Electorate \\
\hline $\begin{array}{l}\text { Opposition } \\
\text { governor }\end{array}$ & $\begin{array}{l}\text { Expectation: less restrictive policy, high } \\
\text { mobility, most protest } \\
\text { Cochabamba: less restrictive policy, high } \\
\text { mobility, high protest } \\
\text { La Paz: less restrictive policy, moderate } \\
\text { mobility, high protest } \\
\text { Oruro: less restrictive policy, high mobility, } \\
\text { some protest } \\
\text { Pando: moderate policy, high mobility, } \\
\text { few protests } \\
\text { Potosí: moderate policy, low mobility, } \\
\text { some protest }\end{array}$ & $\begin{array}{l}\text { Expectation: moderate policy, moderate } \\
\text { mobility, some protest } \\
\text { Beni: strict policy, high mobility, few } \\
\text { protests } \\
\text { Chuquisaca: strict policy, low mobility, } \\
\text { some protest }\end{array}$ \\
\hline $\begin{array}{l}\text { Pro-government } \\
\text { governor }\end{array}$ & $\begin{array}{l}\text { Expectation: strict policy, moderate mobility, } \\
\text { some protest } \\
\text { No departments fit this category }\end{array}$ & $\begin{array}{l}\text { Expectation: strict policy, low mobility, few } \\
\text { protests } \\
\text { Santa Cruz: strict policy, low mobility, } \\
\text { some protest } \\
\text { Tarija: strict policy, low mobility, few } \\
\text { protests }\end{array}$ \\
\hline
\end{tabular}

Table 3

Departmental descriptive statistics

\begin{tabular}{|c|c|c|c|c|c|c|c|c|}
\hline Department & $\begin{array}{c}\text { Population } \\
201{ }^{\star}\end{array}$ & $\begin{array}{c}\text { GDP } \\
\text { per } \\
\text { Capita } \\
2019^{*}\end{array}$ & $\begin{array}{c}\text { Hospital } \\
\text { Beds } \\
2019^{\star}\end{array}$ & $\begin{array}{l}\text { Average } \\
\text { Policy } \\
\text { Index } \\
\text { Score }\end{array}$ & $\begin{array}{c}\text { Average } \\
\text { Mobility } \\
\text { Score }\end{array}$ & $\begin{array}{l}\text { Percent } \\
\text { of } \\
\text { Protests } \\
2020^{\star *}\end{array}$ & $\begin{array}{l}\text { Governor's } \\
\text { Party } 2020\end{array}$ & $\begin{array}{c}\text { MAS } \\
\text { Vote } \\
\text { share } \\
2019^{\star \star \star \star ~}\end{array}$ \\
\hline $\begin{array}{c}\text { Country } \\
\text { totals }\end{array}$ & $11,513,100$ & 3,552 & 14,481 & 85 & -53 & $\begin{array}{l}1138 \\
\text { protest } \\
\text { events }\end{array}$ & & $55 \%$ \\
\hline Beni & 480,308 & 2,403 & 449 & 85 & -43 & $3.1 \%$ & $\mathrm{MAS}^{\star * *}$ & $34 \%$ \\
\hline Chuquisaca & 637,013 & 3,276 & 1,388 & 85 & -60 & $9.9 \%$ & MAS & $49 \%$ \\
\hline Cochabamba & $2,028,639$ & 3,109 & 2,463 & 85 & -55 & $24.1 \%$ & MAS & $66 \%$ \\
\hline La Paz & $2,926,996$ & 3,988 & 3,775 & 84 & -53 & $17 \%$ & Sol.bo & $68 \%$ \\
\hline Oruro & 551,116 & 3,793 & 548 & 86 & -55 & $7.4 \%$ & $\mathrm{MAS}^{\star * *}$ & $63 \%$ \\
\hline Pando & 154,355 & 2,449 & 120 & 83 & -37 & $0.1 \%$ & MAS & $46 \%$ \\
\hline Potosí & 901,555 & 2,802 & 788 & 87 & -56 & $16.9 \%$ & MAS & $58 \%$ \\
\hline Santa Cruz & $3,370,059$ & 3,695 & 4,166 & 86 & -56 & $17.3 \%$ & MDS & $36 \%$ \\
\hline Tarija & 583,330 & 5,329 & 784 & 85 & -56 & $4.1 \%$ & UDA & $42 \%$ \\
\hline
\end{tabular}

confinement phase, reaching a climax in early August. Elections in Bolivia were first scheduled to take place on May 3, but due to the health crisis, elections were postponed to September 6 and then once more to October 18. While the initial delay to September 6 was agreed upon by political actors across the ideological spectrum, the second delay generated conflict and waves of protest that blockaded the country's main cities and highways for almost two weeks (Trigo, Kurmanaev, and McCann 2020). At this point, almost four months had passed since the new coronavirus entered the country, cases were on the rise, and the economy and health systems had collapsed in most departments. For many political actors and analysts, elections were seen as the only pathway to pacify the country and to avoid greater ungovernability (Zegada 2020).

A final ingredient that fueled protests and further undermined the credibility of the interim government was the revelation of corruption scandals directly linked to the provision of medical supplies. In this respect, two findings in the literature are relevant to the Bolivian case. 
Table 4

Primary protest demands during the pandemic

\begin{tabular}{lclc}
\hline & & & \multicolumn{2}{c}{ August-September } \\
\cline { 1 - 2 } Demand & Percentage & & Demand \\
Health & 17.15 & Pro-elections & 54.66 \\
Economic & 15.09 & Health & 12.04 \\
Pro-Elections & 12.13 & Economic & 6.94 \\
Resignation & 8.28 & Other & 5.54 \\
Other & 7.10 & Education & 4.48 \\
Policy change & 6.51 & Resignation & 3.60 \\
Allow work & 6.51 & Allow work & 2.46 \\
Release of person & 5.92 & Policy change & 2.02 \\
Education & 5.03 & Release of person & 1.85 \\
\hline
\end{tabular}

First, it is well established that corruption is tied to disenchantment with political institutions and processes (Morris and Klesner 2010; Seligson 2006; Canache and Allison 2005). Some even suggest that when corruption is pervasive, citizens turn pessimistic about political life and lack the incentives to engage in democratic governance (Svolik 2013; Myerson 2006). Second, corruption is linked to the under-provision of public services (Fried, Lagunes, and Venkataramani 2010; Bearse, Glomm, and Janeba 2000; Hindriks, Keen, and Muthoo 1999; Jain 1998; Murphy, Shleifer, and Vishny 1993). While Bolivia's government put significant financial resources towards fighting the pandemic, de jure policies mean little in practice if the resources meant to enact these policies are diverted into private pockets.

Data from the Americas Barometer by the Latin American Public Opinion Project (LAPOP) in 2019 showed that Bolivians were already concerned about corruption in the public sector: $45.53 \%$ of respondents reported that corruption among public officials was widespread (LAPOP 2019). Hence, individuals entered the pandemic with real concerns about political malfeasance. The corruption cases damaged what little legitimacy the interim government had before the pandemic. While acts of corruption have always been a problem in the country, the case of the ventilators hit a nerve. A survey done by Mercados y Muestras in August 2020 found that 50\% of respondents said that the biggest problem Bolivia faced is corruption, while $28 \%$ said that COVID-19 was the largest problem in the country (Mercados y Muestras 2020). That COVID-19 came as second in the minds of Bolivians during the peak of the country's pandemic indicates that Bolivians see corruption as an obstacle to a sufficient pandemic response.

The national government relaxed policy restrictions in June 2020 in response to protests over its handling of the pandemic, quarantine fatigue, and problems in the healthcare system. On June 1, the national government delegated many pandemic policies to local governments. Opposition governors quickly relaxed containment policies while governors allied with the president maintained strict policies. The one exception was Beni, which had an opposition governor and maintained strict policy. Beni is also the president's home state and experienced a severe outbreak in May and June. Figure 1 shows each department's policy index from March 10 to September 25, 2020, with dashed vertical lines denoting June 1 and September 1.

Unlike other decentralized or federal political systems in the region, Bolivia's national and local governments responded swiftly to the pandemic, taking drastic preventative measures. The national government implemented nine of the ten policy dimensions covered by the Oxford Government Response Tracker within two weeks of the first case. Due to the rapid national response, nearly all subnational governments had a similar policy score for the first two months of the pandemic in Bolivia, as figure 1 and table 3 demonstrate. Subnational governments diverged from each other on June 1, with some relaxing restrictions and others maintaining stringent policies. Subnational governments again converged on policy measures by September 1, when the national government relaxed measures and even the most restrictive departmental governments opened workplaces, transportation, and internal borders.

Policy shows how departmental governments responded to the pandemic and how deviations from national policy largely followed partisan divides. Mobility data from Android cell phones shows where the population complied with quarantine measures and how citizens' behavior diverged across the country. Figure 2 plots daily cellphone mobility by department. The dashed grey horizontal line denotes baseline mobility, which was calculated from cell phone mobility data in January and February 2020. The vertical dashed lines mark June 1 and September 1, when many local governments loosened quarantine restrictions. The weekly peaks and troughs correspond to work days and weekends; the national government maintained a stricter curfew on weekends while allowing local governments to set looser hours during the week.

The mobility data show that Bolivians decreased their collective movement by $75 \%$ from the pre-pandemic 


\section{Figure 1}

\section{Public policy index scores for each Bolivian department}

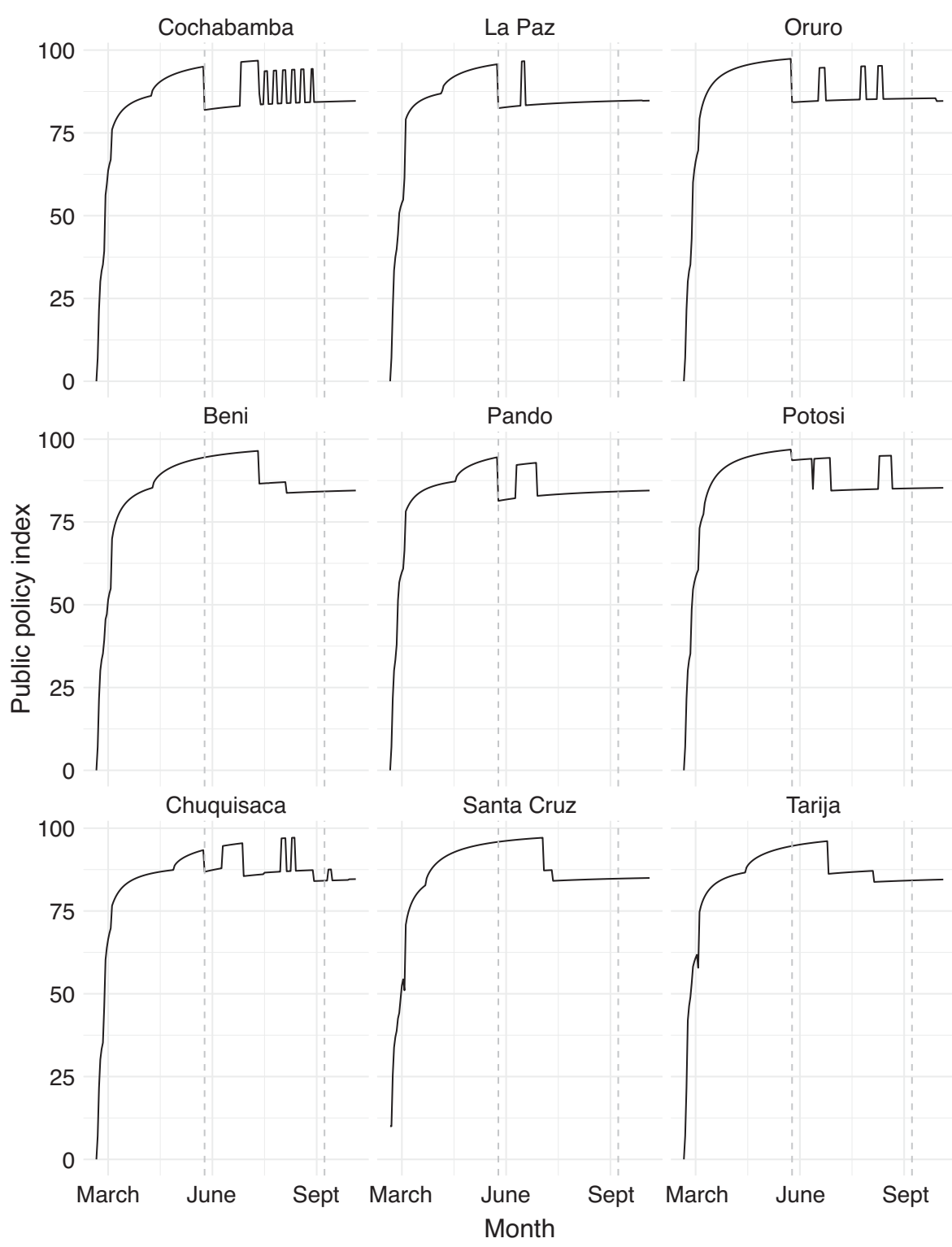

baseline, one of the largest reductions in Latin America. Bolivians across the nine departments complied with the national quarantine but movement creeped up in May with the announcement of the conditional and dynamic quarantine. The decree establishing conditional and dynamic quarantine mentioned that the public policies of each local government, while under their prerogative, should also be set in accordance with the risk conditions of each municipality, which is determined by the Ministry of Health (Ministerio de la Presidencia 28 Mayo 2020). Risk conditions are divided into three: moderate, medium, and high risk, and municipal risk indices are published by the Ministry of Health every week. Also under this framework, and independent of sub-national governments, some public policies remained mandatory throughout the country, such as the closure of schools and borders, a curfew, a national information campaign, the prohibition of events and crowds of people, and the mandatory use of face masks (Ministerio de la Presidencia 28 Mayo 2020).

In opposition departments that opened up on June 1, especially La Paz, Oruro, and Cochabamba, movement increased markedly in June. By contrast, movement in the allied departments of Tarija and Santa Cruz remained low. 


\section{Figure 2}

\section{Cellphone mobility data by department, daily observations}

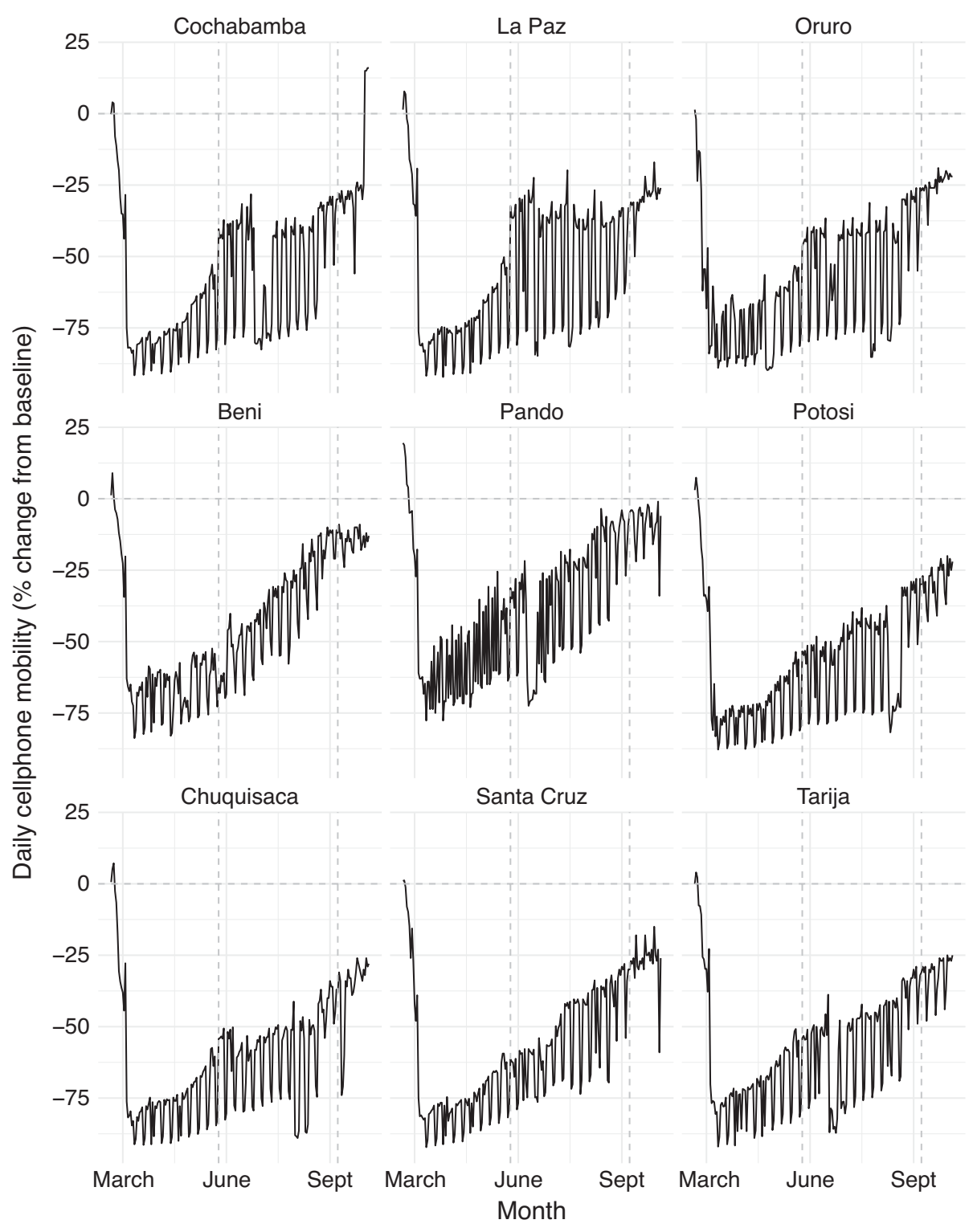

The only departments that returned to pre-pandemic mobility levels were the opposition-led departments of Cochabamba and Pando.

After the national government relaxed restrictions and devolved policy to local governments in June, cases quickly increased in nearly every department. The new coronavirus pandemic first peaked in Bolivia in July, in terms of overall confirmed cases and deaths. Measured in confirmed cases per 100,000 residents, Bolivia's outbreak was higher than some larger regional powers, like Mexico, but lower than Brazil and United States' runaway outbreaks. However, the high positivity rate strongly suggests that many cases went undiagnosed.
When we disaggregate cases per 100,000 residents by department in figure 3, we see different pandemic experiences across Bolivia. Beni and Pando experienced large outbreaks, especially after the latter opposition-led department opened up in June. Opposition-led La Paz, Oruro, and Potosi experienced large outbreaks in July, while progovernment Tarija experienced a large outbreak after loosening restrictions in July. The dashed vertical lines mark June 1 and September 1.

At the height of the pandemic, and with several health systems collapsing across departments, individuals sought out their own treatments. Beni, an opposition-led department, was the first to report an increase in the number of 
individuals self-medicating with hydroxychloroquine, traditional medicine, and other over-the-counter options as shortages, poverty, collapsed hospitals, and misinformation made professional medical help difficult to access (Peredo 2020; Correo del Sur 2020). The health crisis in Beni was so severe that local authorities passed a law declaring a health disaster in the department in May (Gobierno Autonomo Departamental del Beni 2020)

Mortality data by department and month paints a more unequal and politically divided picture in figure 4. We collected data on confirmed COVID-19 deaths daily from the nine departments, but these deaths only count people who tested positive for COVID-19 before they died. With a severe national testing shortage, the official number of deaths attributed to COVID-19 is a significant undercount; many people died before reaching a hospital or seeing a doctor. We collected data on total deaths reported to SERECI by department and month, using data from The New York Times and the SERECI (Trigo, Kurmanaev, and McCann 2020).

Figure 4 shows a dramatic spike in deaths per 100,000 residents across the country in July. We calculated the average number of deaths for each department by month from 2016 to 2019 and used this as a baseline measure, reported in the solid grey line in figure 4 . The dashed gray line tracks the number of confirmed COVID-19 deaths. The solid black line is the total number of deaths reported in each department. The SERECI offices closed in March and April, accounting for the drop at the beginning of quarantine. Figure 4 tabulates deaths per 100,000 people from March to August 2020.

Figure 4 shows huge disparities in the pandemic's death toll across Bolivia. In Beni and Pando, opposition-led departments and the two poorest departments with the fewest hospitals and beds per capita, the number of overall deaths climbed to over seven times the average number of deaths in July. In the opposition-led departments of La Paz and Oruro, the number of deaths was nearly five times the average in July. In Cochabamba, it was three times the average. In allied Tarija, the department with the most wealth per capita and the most cautious regional government, deaths peaked in August at twice the normal rate.

The data illustrate our suggestion that partisan policies explain as much or more than structural factors. Looking at the case of La Paz, the administrative capital, we can see how policy changes in opposition to the national government coincided with high case counts and deaths, even though the department has more funds and public health resources than most departments. Prior to the pandemic, La Paz and Santa Cruz had more hospitals and more hospital beds per capita than other departments. La Paz has a network of private doctors and clinics in addition to the large public hospitals and there are medical supply facilities in the greater $\mathrm{La} \mathrm{Paz}$ metropolitan area.
Additionally, per capita income and savings are above the national average. The La Paz city and departmental governments are more responsive and efficient than many other local governments and employ many experienced bureaucrats, including teams who have worked on localized epidemics in the past. Still, the governor quickly rolled back lockdown policies on June 1 with confirmed cases and deaths rapidly increasing soon after. The governor did not return to lockdown following this increase and in July 2020, La Paz recorded five times as many deaths as the department typically records in July. This staggering death toll was the third highest (measured as a percentage increase over the average) in the country after Beni and Pando, despite La Paz's considerable resource and structural advantages over most other departments. The trend also holds at the municipal level with some of the highest death tolls in municipalities with substantial capacity but opposition mayors including the municipalities of La Paz, El Alto, Cochabamba, Sucre, and Sacaba, among others.

After two hundred days of political and public health crises, data from protests, policy implementation, cases, and deaths show that opposition-led departments were more likely to relax their policies and then experience a spike in cases and deaths, while opposition-dominated populations were more likely to protest and move around in defiance of quarantine. On a population-adjusted basis, poor, opposition-led departments suffered the worst increases in deaths.

\section{Illustrative Cases}

Bolivia entered the new coronavirus pandemic with an interim government that did not enjoy generalized support or trust, and with a highly polarized society and decentralized political system where election losers showed alarmingly low levels of support for the interim government. These two factors shaped how the government handled the pandemic and the degree of compliance from the population. We delve further into pandemic experiences in two large departments on opposite sides of the legitimacy divide in order to illustrate our argument. These two cases illustrate the opposition governor and electorate and aligned governor and electorate categories from table 1 . We do not present a full case study on the third category in table 1 because it encompasses experiences that mix traits of the first two categories, producing more moderate outcomes. Moreover, the vote share of the departments in this category is more evenly distributed among competing parties lending to a more evenly divided electorate. In Beni, Comunidad Ciudadana (CC) and the MAS each got $34.77 \%$ and $34.93 \%$ of the vote in the 2019 presidential elections respectively. In Chuquisaca, the vote share was $44.22 \%$ and $42.35 \%$ for CC and MAS each. 


\section{Figure 3}

\section{Daily cases per 100,000 by department}

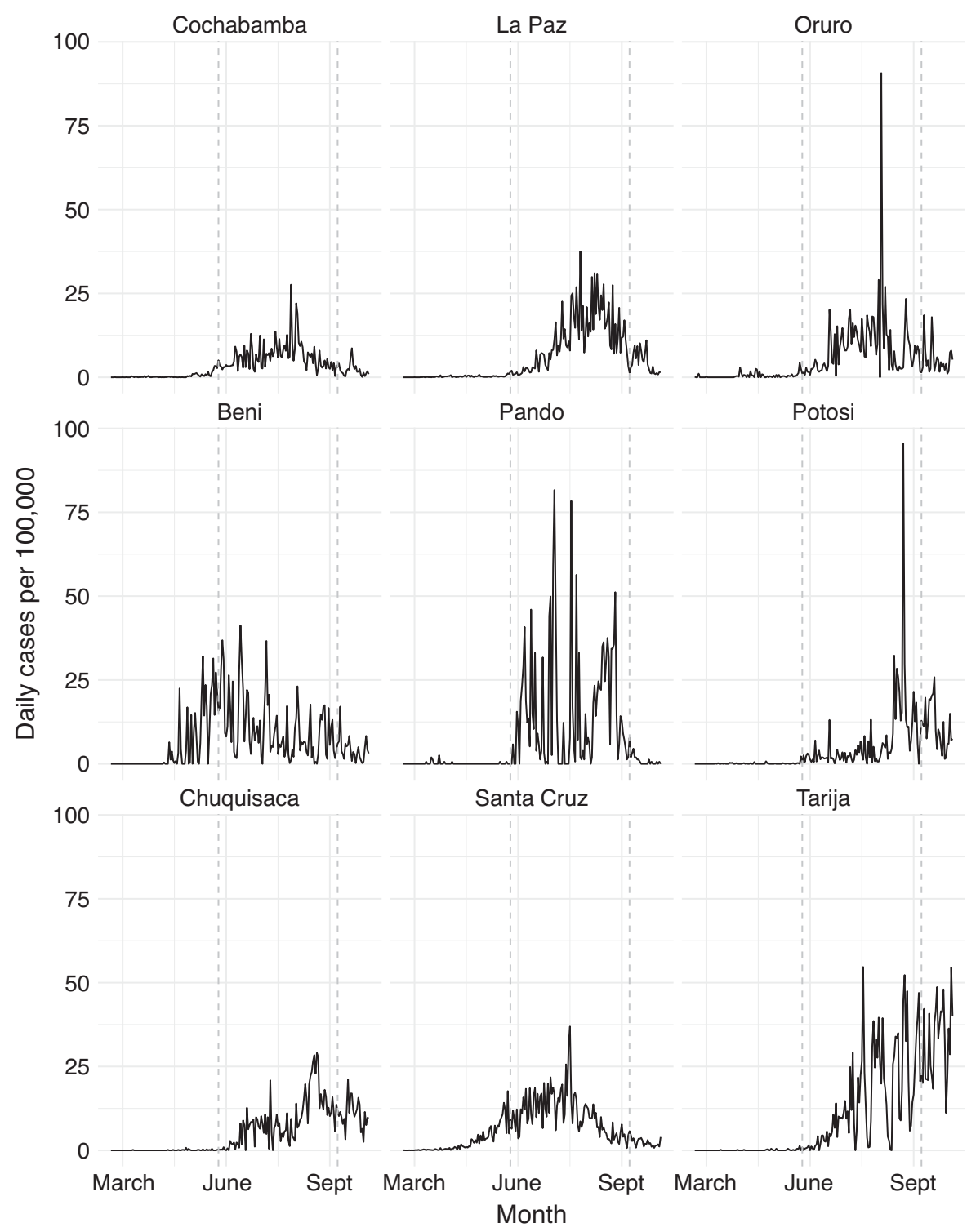

\section{Cochabamba}

Cochabamba offers an illustrative case for our classification of opposition governor and opposition electorate and our theoretical expectations. The MAS began in Cochabamba as the political vehicle for locally powerful organizations of coca growers, farmers, and indigenous people. The governor of Cochabamba, Esther Soria, is from the MAS, and the MAS candidates easily won the department in the 2019 and 2020 presidential elections. Cochabamba's citizens and political leaders vocally opposed the ascension of Añez in 2019 and resisted her policies in 2020.

Referring back to our theoretical expectations in tables 1 and 2, we expect that policy in Cochabamba was less restrictive than the national average and that citizens moved around more and protested more than citizens in pro-Añez departments. The qualitative and quantitative data match our expectations. Cochabamba's governor and many mayors relaxed policy as soon as they legally could and Cochabamba's departmental policy score is below the country's average. Cochabamba is also one of the only departments where mobility returned to pre-pandemic levels.

Cochabamba experienced a massive wave of protests between March and September and recorded the highest number of protests of any department in the country. Cochabamba hosted $24 \%$ of all protest events registered in 


\section{Figure 4}

\section{Deaths per 100,000 people by department and month.}

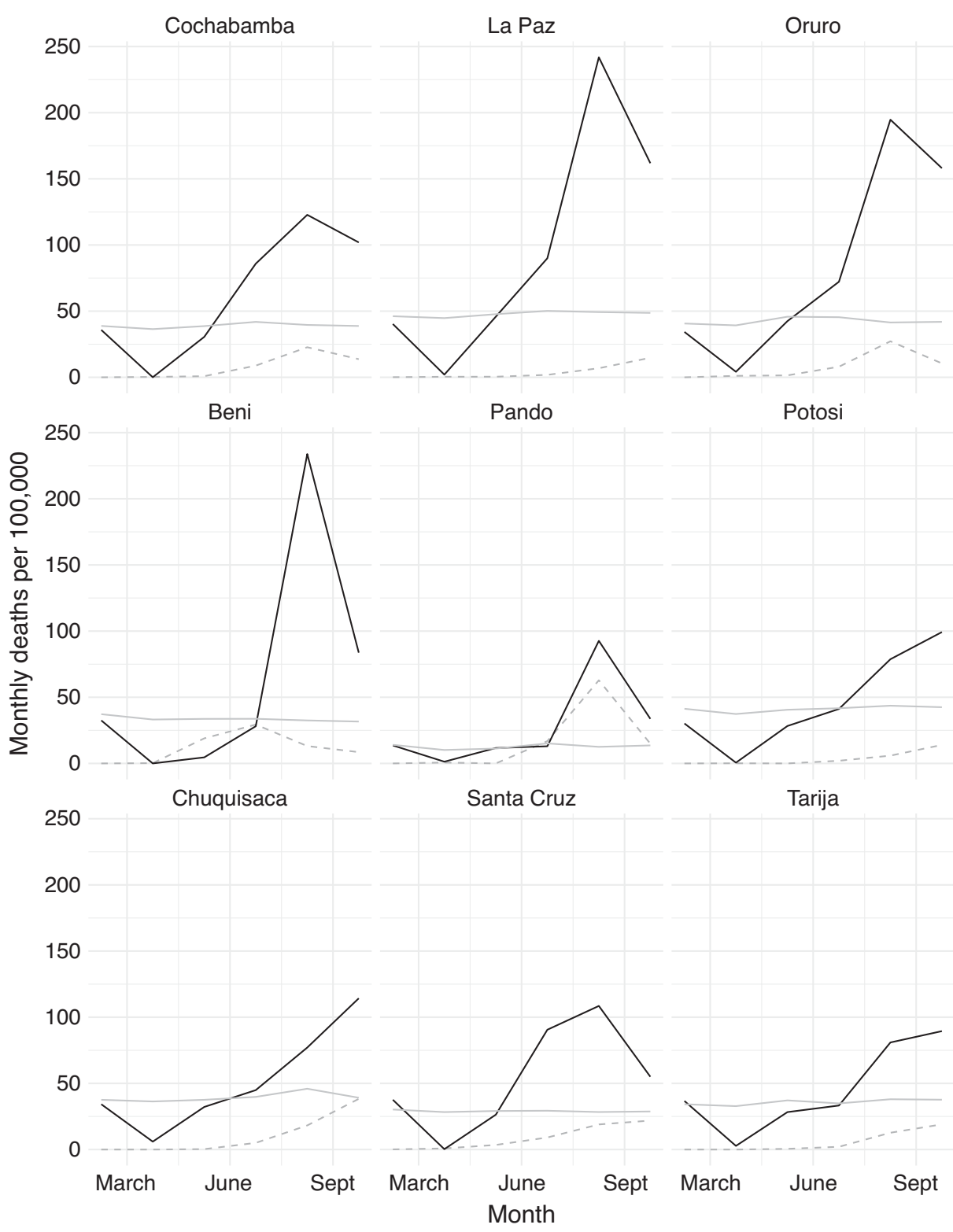

the country from March to September. Protests against quarantine restrictions and for elections were particularly common. The municipalities that saw the most protest activity are agricultural centers and towns known as MAS strongholds, including Colomi, Entre Rios, Puerto Villarroel, Punata, Quillacollo, Sacaba, Shinahota, Sipe Sipe, Tapacari, Tiquipaya, Tiraque, and Villa Tunari. Proelection protests were particularly contentious in this region of the country: protests blockaded large sections of the department for almost two weeks in July and August. Government health officials said the blockades reduced the supply of oxygen and other medical supplies, but protest organizers claimed they were allowing medical workers, medical suppliers, and fuel to pass through the blockades (Trigo, Kurmanaev,and McCann 2020).

The relationship between the Añez administration and Governor Soria was contentious throughout the pandemic. In May, the interim government intervened in Cochabamba's departmental health services, and the Ministry of Health dismissed Eddy Calvimontes as Cochabamba's departmental health director and appointed Miguel Ángel Delgado as the interim technical head of this institution. Governor Soria rejected this intervention and ratified Calvimontes as head of the Health Services, 
which led to two directors working in parallel and battling over jurisdiction and legitimacy at the height of the public health crisis.

The rhetoric used by several mayors from the MAS also ran contrary to the national-level information campaign on COVID-19. Notably, the mayor of Entre Rios municipality, Aurelio Rojas, who later died of COVID-19, declared that the virus was an invention (Pagina Siete Junio 2020). Several other mayors in Cochabamba and La Paz made similar statements from "the virus doesn't exist" to "it is an invention from the right" (Brujula Digital Mayo 2020). Even Governor Soria allegedly made statements that cast doubt on the existence of the virus (Pagina Siete Julio 2020).

We see health policy decisions within the department falling along partisan lines as well. Not all municipalities, political leaders, and voters in Cochabamba support the MAS and it is exactly in those few municipalities controlled by other political parties where mayors enacted strict containment policy. In the city of Cochabamba (the department and its capital city share the same name), the mayor was not MAS-affiliated but belonged to the Social Democratic Movement party (Movimiento Democrata Social or MDS) and imposed earlier and stricter restrictions than the departmental government throughout the pandemic. Still, with a largely opposition electorate, the city of Cochabamba experienced moderate mobility and some protests. Hence, in this case, our theoretical expectations hold at the municipal level as well as the department level.

\section{Santa Cruz}

Santa Cruz illustrates the pro-government governor and divided electorate category and our expectations for that category. The governor of Santa Cruz, Ruben Costas, is from the Social Democratic Movement party (Movimiento Democrata Social or MDS) and the MAS did not reach a majority of the vote in either the 2019 or 2020 presidential elections. Short-lived local parties Citizens' Community (Comunidad Ciudadana or CC) won Santa Cruz in 2019 and We Believe (Creemos) won in 2020. Under these conditions, we expected the department to enact strict containment policies and its citizens to largely comply by staying home, reducing mobility, and not protesting. Indeed, the governor of Santa Cruz publicly backed all measures taken by the central government from the start of the pandemic. The department started with the highest policy index in the countryeleven, by enacting containment policies on the first day that cases were identified - and consistently maintained above average levels of restrictions. Santa Cruz's citizens drastically reduced their mobility in March and while transportation increased slowly, mobility remained far below pre-pandemic levels after 200 days.
Of all protest events registered in the country from March to September, Santa Cruz witnessed 17.3\%, the second highest after Cochabamba. While this is contrary to our expectations at the departmental level, our theoretical expectations are borne out when we look at the geographic distribution of protests within the department: protests were led by MAS supporters and concentrated in municipalities where MAS won a majority of votes in both 2019 and 2020. These included Yapacani, San Julián, Cuatro Canadas, San Javier, Ascención de Guarayos, Samaipata, and Pailón. In late July and early August, MAS supporters protested across the country for the Añez administration to stop rescheduling elections. In areas of Santa Cruz where vote margins in the 2019 election had been close, confrontations ensued between pro-Añez and pro-MAS supporters. MAS supporters set up blockades on dozens of roads and highways around Santa Cruz and proAñez demonstrators in the city of Santa Cruz marched to blockades in order to dismantle them (Santa Cruz, like Cochabamba, is the name of the department and its capital city). Some of these confrontations turned violent and led to street battles between opposition and pro-government citizens (Fides 2020). During the protests, opposition and pro-government supporters broke the department's COVID-19 prevention measures that placed restrictions on gatherings and public events. Anti-lockdown protests were also common in regions like Yapacani, a MAS stronghold, throughout the quarantine period (El Deber 2020). Similar to the case study of Cochabamba, a closer examination of the pandemic experience in the Santa Cruz department demonstrates how citizens' and local leaders' pandemic policies and compliance fell along largely partisan lines.

\section{National Policymaking and Chlorine Dioxide}

National policymaking and the debates between the Añez administration and the MAS-dominated legislature further illustrate how pandemic policy broke down along partisan lines, in occasionally counterintuitive and dangerous ways. The relationship between the interim executive and the legislature was characterized by constant clashes and an evident lack of consensus on public health policies related to the management of the pandemic. Of the many conflicts between the two branches of government, two are worth noting: the use of chlorine dioxide and the approval of International Monetary Fund (IMF) credits for a health stimulus check known as the Bono Salud.

The MAS-dominated legislature enacted a law promoting chlorine dioxide as a treatment for COVID-19, rejecting recommendations from the Añez-appointed Minister of Health and against the advice of the Bolivian and international scientific community (Gaceta Oficial del Estado Plurinacional de Bolivia 2020, Trigo, Kurmanaev, 
and Cabrera 2020). Chlorine dioxide is a bleach variant used to clean floors and can be toxic if ingested. Pharmacies across Bolivia sold chlorine dioxide as a tonic and it became particularly sought after in MAS-dominated areas. The same dynamic was reproduced at the subnational level where MAS-dominated departmental assemblies in La Paz and Cochabamba passed laws approving the use and distribution of chlorine dioxide, with Cochabamba's law including the distribution of the chemical compound to the population free of charge. The governors of $\mathrm{La} \mathrm{Paz}$ and Cochabamba, who opposed Añez, signed department legislation. After these laws were enacted, the Ministry of Health, as well as several departmental health services, continued to release information warning against the use of chlorine dioxide (Los Tiempos 2020; Brujula Digital Julio 2020).

The fracture between the executive and the legislature came to the fore again with the approval of IMF credits to ease the economic crisis. The strict quarantine between March and May 2020 paralyzed economic activity across Bolivia and the Añez administration turned to the IMF for a loan. The Añez administration used part of the loan to write the Bono Salud stimulus checks. When in power, the MAS had promoted several huge universal social assistance policies similar to Bono Salud. Massive redistribution, particularly during crisis, is a core tenet of the MAS platform and ideology. Additionally, the MAS voter base suffered bigger economic losses from the lockdown than Añez's support base (Blofield and Filgueira 2020). Still, the legislative assembly was loath to hand Añez anything resembling a victory and thus voted to stop the approval of credits, arguing a lack of documentation. Moreover, the MAS as well as other political parties and grassroots associations argued that the interim president was using the health stimulus to run an electoral campaign (Los Tiempos 2020; Corz and Aguirre 2020)

The departmental and legislative case studies illustrate how a crisis of legitimacy at the national level politicized public health policy during the pandemic. Political opponents at the national, departmental, and municipal level clashed and undermined each other's policies - even when doing so endangered constituents and went against their professed ideology.

\section{Conclusion}

Bolivia exemplifies the challenges of an effective policy response to a crisis in the context of high polarization and low government legitimacy. The decision to decentralize health policy under these conditions furthered the crisis of legitimacy that hampered the pandemic response across Bolivia. The challenge of implementing unpopular policy responses that limit personal freedoms, such as issuing stay at home orders and mask mandates, are enormous, even for strong, legitimate, and popular governments. The lack of legitimacy faced by the Bolivian national government was not resolved by transferring health policy authority to local governments. Instead, the deep political divisions over the legitimacy of the government continued to undermine compliance with public health measures and fueled protests against national and local governments. Decentralizing health policy in this context also exacerbated underlying inequalities and created more opportunities for opposition leaders to politicize the crisis, contributing to devastating losses of life.

Countries around the world, including the United States, Brazil, Mexico, Argentina, India, South Africa, Venezuela, and Chile, have also experienced polarization and uneven pandemic responses. Across the world, low legitimacy and political polarization undermined compliance with public health directives as feuds between national and regional governments politicized mask use, quarantine measures, and social distancing, as well as spread misinformation. In the United States, Brazil, and Bolivia, people who did not trust government institutions self-medicated with bleach and related products. WhatsApp and YouTube replaced health ministries as reliable sources of information in Bolivia, Venezuela, Brazil, and the United States.

Importantly, the case of Bolivia suggests that polarization and its partisan dynamics, not ideology, drive the politicization of health policy. In Bolivia, a right-wing government instituted strict policy and leftist governors relaxed it while leftist citizens devoured dangerous misinformation and chlorine dioxide. This runs counter to the lax response of right-wing governments in the United States and Brazil, who peddled misinformation and hydroxychloroquine to their own supporters. Bolivia's experience does mirror the United States' and Brazil's polarized politics and partisan, rather than ideological, struggles over policy. Our findings suggest that during health crises in a polarized environment, the response becomes extremely politicized and the opposition will resist the national government's policy regardless of ideology.

\section{Supplementary Materials}

Methodological Appendix.

To view supplementary material for this article, please visit http://doi.org/10.1017/S1537592721001183.

\section{Acknowledgements}

The authors would like to thank the University of Miami Observatory for the Containment of COVID-19 in the Americas for bringing them in as the Bolivia team and serving as our virtual institutional home during the pandemic. They are grateful to Anatoly Kurmanaev, María Silvia Trigo, Sofia Villamil, and The New York Times for sharing mortality data obtained from the Bolivian Civil Registry. They thank Clara Burney Collison, Katie Garcia Martinez, and Layla Claure for research assistance. They 
deeply appreciate the feedback from four anonymous reviewers and the work of the editorial team. All errors are our own.

\section{Note}

1 Departments are the largest sub-national unit in the Bolivian government, somewhat similar to U.S. states. There are nine departments in the country.

\section{References}

Agencia Boliviana de Información. 2020. "El coronavirus se cobró la vida de 125 médicos en seis meses de pandemia." (https://www1.abi.bo/abi_/?i=455573).

Alesina, Alberto., Reza Baqir, and William Easterly. 1999. "Public Goods and Ethnic Divisions." Quarterly Journal of Economics 114(4): 1243-84.

Anria, Santiago, and Sara Niedzwiecki. 2016. "Social Movements and Social Policy: The Bolivian Renta Dignidad." Studies in Comparative International Development 51(3): 308-27.

Anria, Santiago. 2018. When Movements Become Parties: The Bolivian MAS in Comparative Perspective. New York: Cambridge University Press.

Anria, Santiago, and Kenneth Roberts. 2019. "Bolivia after Morales.” Foreign Affairs (https://www. foreignaffairs.com/articles/bolivia/2019-11-21/boliviaafter-morales).

AzurduyArequipa, Marcelo. 2020. Polarización a la Boliviana. In Polarización y Conflicto: Midiendo los Riesgos de la Violencia. ed. Roberto Laserna, 43-51. Amsterdam: Ediciones Ceres Press

Baekkeskov, Erik, and Olivier Rubin. 2014. "Why Pandemic Response Is Unique: Powerful Experts and Hands-off Political Leaders." Disaster Prevention and Management 23(1): 81-93.

Bearse, Peter, Gerhard Glomm, and Eckhard Janeba. 2000. "Why Poor Countries Rely Mostly on Redistribution In-Kind. Journal of Public Economics 75(3): 463-81.

Blofield, Merike, and Fernando Filgueira. 2020. "COVID19 and Latin America: Social Impact, Policies and a Fiscal Case for an Emergency Social Protection Floor." CIPPEC Social Protection Program (https:// www.cippec.org/wp-content/uploads/2020/04/ Blofield-Filgueira-2020-1.pdf).

Bolivia, Ministerio de la Presidencia [Jeanine Añez]. Decreto Supremo 4199. 21 Marzo 2020. La Paz: Gaceta Oficial del Estado Plurinacional de Bolivia

Bolivia, Ministerio de la Presidencia [Jeanine Añez]. Decreto Supremo 4179. 12 marzo 2020. Gaceta Oficial del Estado Plurinacional de Bolivia.

Ministerio de la Presidencia [Jeanine Añez]. Decreto Supremo 4192. 16 marzo 2020. Gaceta Oficial del Estado Plurinacional de Bolivia.
Ministerio de la Presidencia [Jeanine Añez]. Decreto Supremo 4196. 17 marzo 2020. Gaceta Oficial del Estado Plurinacional de Bolivia.

Ministerio de la Presidencia [Jeanine Añez]. Decreto Supremo 4229. 29 abril 2020. Gaceta Oficial del Estado Plurinacional de Bolivia.

Ministerio de la Presidencia [Jeanine Añez]. Decreto Supremo 4245. 28 mayo 2020. Gaceta Oficial del Estado Plurinacional de Bolivia

Ministerio de la Presidencia [Jeanine Añez]. Decreto Supremo 4314. 27 agosto 2020. Gaceta Oficial del Estado Plurinacional de Bolivia.

Autoridad de Regulacion y Fiscalizacion de Telecomunicaciones y Transporte. Estado de Situación del Internet en Bolivia: Primer Trimestre 2020.

Braithwaite, Valerie, and Margaret Levi, eds. 1998. Trust and Governance. New York: Russell Sage Foundation.

Brujula Digital. 27 Mayo 2020. "En el Trópico de Cochabamba se incrementan los casos de Covid -19 de 5 a 54 en solo 10 días" Sociedad, Brújula Digital. https:// brujuladigital.net/sociedad/en-el-tropico-decochabamba-se-incrementan-los-casos-de-covid-19de-5-a-54-en-solo-10-dias?fbclid=IwAR2iQ6n5co A7nT8xwlsis1 pijcDOrYEriavD9dmBbu0CAjcn Uban8RuIbuQ

Brújula Digital. 19 Julio 2020. "Prensa internacional critica que en Bolivia se venda dióxido de cloro como medicina "milagrosa” contra COVID-19." Politica, Brujula Digital. https://www.brujuladigital.net/ politica/prensa-internacional-critica-que-en-boliviase-venda-dioxido-de-cloro-como-medicina-milagrosacontra-covid-19

Carothers, Thomas, and Andrew O'Donahue. 2019. Democracies Divided: The Global Challenge of Political Polarization. Washington, D.C.: The Brookings Institution.

Canache, Damarys, and Michael E. Allison. 2005. "Perceptions of Political Corruption in Latin American Democracies." Latin American Politics and Society 47(3), 91-111.

Chaski Clandestina. 2019. "Bolivia en estado de 'Shock": a una semana de la masacre de Senkata." Chaski Clandestina, November 28. (https://chaskiclandestina. org/2019/11/29/bolivia-en-estado-de-shock/).

Condori R., Betty. 2020. "De 1.200 médicos y enfermeras, 420 están complicados con el virus y 1.100 no tienen Seguro," 12 de Julio. Opinion. (https:// www.opinion.com.bo/articulo/cochabamba/1200medicos-enfermeras-420-estan-complicados-virus1100-tienen-seguro/20200711184037777177.html).

Cornelson, Kirsten., and Boriana Miloucheva. 2020. "Political Polarization, Social Fragmentation, and Cooperation during a Pandemic." Working Paper No. 663. Department of Economics, University of Toronto. 
Correo del Sur. 2020. "La automedicación y la escasez de insumos médicos agravan la crisis de Beni." Correo del Sur, 24 de Mayo. (https://correodelsur.com/ sociedad/20200524_la-automedicacion-y-la-escasezde-insumos-medicos-agravan-la-crisis-de-beni.html).

Corz, Carlos, and Lilliana Aquirre 2020. "Áñez usa discurso para hacer campaña; el MAS y CC la denunciarán ante el TSE.” La Razón. (https://www.larazon.com/nacional/2020/09/13/anez-usa-discursopara-hacer-campana-el-mas-y-cc-la-denunciaran-anteel-tse/).

AlejaCuevas. 2020. En 24 días, 97 médicos y enfermeras fueron contagiados con el COVID-19 en Beni. $\mathrm{La}$ Razon. 13 de Mayo. (https://www.la-razon.com/ sociedad/2020/05/13/en-24-dias-97-medicos-yenfermeras-fueron-contagiados-con-el-covid-19en-beni/).

Derpic, Jorge. 2019. "Bolivia after Morales: Power Struggles and Shifting Alliances in the Run-Up to New Elections." London School of Economics Blogs, November 30 (https://blogs.lse.ac.uk/latamcaribbean/2019/11/ 30/bolivia-after-morales-power-struggles-and-shiftingalliances-in-the-run-up-to-new-elections/).

_ _ 2020. "Tras la caída de Evo Morales, el largo y letal camino de Bolivia hacia nuevas elecciones." Centro de Investigación Periodística Chile. (https://

ciperchile.cl/2020/01/21/tras-la-caida-de-evo-moralesel-largo-y-letal-camino-de-bolivia-hacia-nuevaselecciones/).

Eaton, Kent. 2011. "Conservative Autonomy Movements: Territorial dimensions of Ideological Conflict in Bolivia and Ecuador." Comparative Politics 43(3): 291-310.

\section{- 2017. Territory and Ideology in Latin America: Policy} Conflicts between National and Subnational Governments. Oxford: Oxford University Press.

El Derber. 2020 "En Yapacaní intentan marchar en plena cuarentena y tres personas terminan arrestadas." El Deber, 6 Abril (https://eldeber.com.bo/santa-cruz/enyapacani-intentan-marchar-en-plena-cuarentena-ytres-personas-terminan-arrestadas_173235).

Escalera-Antezana, Juan Pablo, Nicolas Freddy LizonFerrufino, Americo Maldonado-Alanoca, Gricel Alarcón-De-la-Vega, Lucia Elena Alvarado-Arnez, María Alejandra Balderrama-Saavedra, D. Katterine Bonilla-Aldana, and Alfonso J. Rodríguez-Morales. 2020. "Clinical features of cases and a cluster of Coronavirus Disease 2019 (COVID-19) in Bolivia imported from Italy and Spain." Travel Medicine and Infectious Disease. doi: 10.1016/j.tmaid.2020.101653

Faguet, Jean-Paul. 2012. Decentralization and Popular Democracy: Governance from Below in Bolivia. Ann Arbor: University of Michigan Press.

Farthing, Linda. 2019. “An Opportunity Squandered? Elites, Social Movements, and the Government of
Evo Morales". Latin American Perspectives 46(1): 212-29.

Farthing, Linda, and Benjamin H. Kohl. 2014. Evo's Bolivia: Continuity and change. Austin: University of Texas Press.

Fenwick, Tracy Beck. 2016. Avoiding Governors : Federalism, Democracy, and Poverty Alleviation in Brazil and Argentina. Notre Dame, Indiana : University of Notre Dame Press, 2016.

Fides. 2020. "El MAS admite que participa en los bloqueos de caminos y que la movilización es política." Fides, Politica, 8 Agosto (https://

www.noticiasfides.com/nacional/politica/el-masadmite-que-participa-en-los-bloqueos-de-caminos-yque-la-movilizacion-es-politica-405821).

Fowler, Erika Franklin, and Sarah E. Gollust. 2015. "The Content and Effect of Politicized Health Controversies." ANNALS of the American Academy of Political and Social Science 658(1): 155-71.

Fried, Brian J., Paul Lagunes, and Atheendar Venkataramani. 2010. "Corruption and Inequality at the Crossroad: A Multi-Method Study of Bribery and Discrimination in Latin America." Latin American Research Review 45(1): 76-97.

Gaceta Oficial Del Estado Plurinacional de Bolivia. 2020 Ley N\#1351: Ley que Regula la Elaboración, Comercialización, Suministro y uso Consentido de la Solución De Dióxido de Cloro (SDC) como Prevencion y Tratamiento ante la Pandemia del Coronavirus. (http://www.gacetaoficialdebolivia. gob.bo/normas/verGratis_gob/168340).

Gobierno Autónomo Departamental del Beni. Gaceta Oficial. Trinidad, Beni. Mayo 2020. (https:// www.beni.gob.bo/index.php?option=com_k2\&view= item\&layout=item \& $\alpha i d=10 \&$ Itemid $=130$ ).

Google LLC. 2020. "Google COVID-19 Community Mobility Reports". Septiembre (https://www.google. com/covid19/mobility/).

Gray-Molina, George, Ernesto Perez de Rada, and Ernesto Yañez. 1999. "Transparency and Accountability in Bolivia: Does Voice Matter?” Inter-American Development Bank Research Paper Series No. 113. http://doi.org/10.2139/ssrn.1814658

Hale, Thomas, Noam Angrist, Emily Cameron-Blake, Laura Hallas, Beatriz Kira, Saptarshi Majumdar, Anna Petherick, Toby Phillips, Helen Tatlow, and Samuel Webster. 2020. Oxford COVID-19 Government Response Tracker, Blavatnik School of Government. (https://www.bsg.ox.ac.uk/research/research-projects/ covid-19-government-response-tracker).

Hardin, Russell. 1991. "Trusting Persons, Trusting Institutions." Strategy and Choice 185:185-209.

Hindriks, Jean, Michael Keen, and Abhinary Muthoo. 1999. "Corruption, Extortion and Evasion. Journal of Public Economics 74(3): 395-430. 
Hoey, Lesli. 2017. "Reclaiming the Authority to Plan: How the Legacy of Structural Adjustment Affected Bolivia's Effort to Recentralize Nutrition Planning." World Development 91: 100-12.

Hummel, Calla, V. Ximena Velasco Guachalla, Jami Nelson-Nuñez, and Carew Boulding. 2020. "Bolivia: lecciones sobre los primeros seis meses de la pandemia de SARS-CoV-2." Temas Sociales 47: 98-129.

Hummel, Calla, Felicia Marie Knaul, Michael Touchton, V. Ximena Velasco Guachalla, Jami Nelson-Nuñez, and Carew Boulding. 2021. "Poverty, Precarious Work, and the COVID-1 Pandemic: Lessons from Bolivia." Lancet Global Health. https:// doi.org/10.1016/S2214-109X(21)00001-2

Jain, Arvind K. 1998. "Models of Corruption." In Economics of Corruption, ed. A. K. Jain, 13-34. Boston, MA: Kluwer.

Kitroeff, Natalie y Mitra Taj. 2020. "Latin America's Virus Villains: Corrupt Officials Collude with Price Gougers for Body Bags and Flimsy Masks." New York Times, June 20 (https://www.nytimes.com/ 2020/06/20/world/americas/coronavirus-latinamerica-corruption.html?searchResultPosition=3).

Knaul, Felicia et al. 2020. "Lejos del Distanciamiento: El Desempeño Estatal en Aplicar Políticas de Salud Pública para Vencer el COVID-19 en México." University of Miami Institute for the Advanced Study of the Americas Working Paper.

Laserna, Roberto. 2020. Polarización y Conflicto: Midiendo los Riesgos de la Violencia. Amsterdam: Ediciones Ceres Press.

Lehoucq, F. (2020). "Bolivia’s Citizen Revolt." Journal of Democracy 31(3): 130-144.

Levi, Margaret. (1997). Consent, dissent, and patriotism Cambridge: Cambridge University Press.

López-Calva, Luis Felipe. 2019. "Ruling for the Few? How Weak: egitimacy Can Hinder Compliance and Cooperation in LAC Countries." UNDP Latin America and the Caribbean. Blog Post, April. (https:// www.latinamerica.undp.org/content/rblac/en/home/ presscenter/director-s-graph-for-thought/ruling-forthe-few--how-weak-legitimacy-can-hindercompliance-an.html).

Los Tiempos. 2020. "Sedes no recomienda uso del dióxido de cloro, pese a la aprobación de la Asamblea." Los Tiempos, Actualidad 23 Julio. (https:// www.lostiempos.com/actualidad/pais/20200723/ sedes-no-recomienda-uso-del-dioxido-cloro-peseaprobacion-asamblea).

Madrid, Raul L. 2012. The Rise of Ethnic Politics in Latin America. New York: Cambridge University Press.

Mamani, Gilber. 2020. "Evo Morales and the Bolivian Spring." Intercontinental Cry (https://intercontinen talcry.org/evo-morales-and-the-bolivian-spring/).
Marks, Danny, and Louis Lebel. 2016. "Disaster Governance and the Scalar Politics of Incomplete Decentralization: Fragmented and Contested Responses to the 2011 Floods in Central Thailand." Habitat International 52:57-66. http://doi.org/ 10.1016/j.habitatint.2015.08.024

McNulty, Stephanie. 2019. Democracy from Above: The Unfulfilled Promise of Nationally Mandated Participatory Reforms. Stanford, CA: Stanford University Press.

Mercados y Muestras. 2020. "Informe Encuesta Nacional." Presentación de datos, Agosto. (https://www.minsalud.gob.bo/3967-ministro-desalud-reporta-dos-casos-confirmados-de-coronavirusy-pide-calma-a-la-poblacion).

Morris, Stephen D., and Joseph L. Klesner. 2010. "Corruption and Trust: Theoretical Considerations and Evidence from Mexico." Comparative Political Studies 43(10): 1258-85.

Murphy, Kevin M., Andrei Shleifer, and Robert W. Vishny. 1993. "Why Is Rent-Seeking So Costly to Growth?" American Economic Review 83(2): 409-14.

Myerson, Roger B. 2006. "Federalism and Incentives for Success of Democracy." Quarterly Journal of Political Science 1(1): 3-23.

Niedzwiecki, Sara. 2016. "Social Policies, Attribution of Responsibility, and Political Alignments: A Subnational Analysis of Argentina and Brazil." Comparative Political Studies 49(4): 457-98.

- 2018. Uneven Social Policies: The Politics of Subnational Variation in Latin America. New York: Cambridge University Press.

Niedzwiecki, Sara, and Santiago Anria. 2019. "Participatory Social Policies: Diverging Patterns in Brazil and Bolivia." Latin American Politics and Society 61(2): 115-37.

O'Neill, Kathleen. 2005. Decentralizing the State: Elections, Parties, and Local Power in the Andes. New York: Cambridge University Press.

Our World in Data. 2020. Bolivia: Coronavirus Pandemic. (https://ourworldindata.org/coronavirus/ country/bolivia?country $=-\mathrm{BOL}$ ).

Pagina Siete. 2020. "Alcalde que dijo que el coronavirus era un "invento" muere con Covid-19." Pagina Siete, 17 Junio (https://www.paginasiete.bo/sociedad/ 2020/6/17/alcalde-que-dijo-que-el-coronavirus-eraun-invento-muere-con-covid-19-258697.html). _ 2020. "Atribuyen audio a la gobernadora de Cochabamba en el que duda que exista el Covid-19” Pagina Siete, 9 Julio (https://www.paginasiete.bo/ sociedad/2020/7/9/atribuyen-audio-la-gobernadorade-cochabamba-en-el-que-duda-que-exista-el-covid19-260815.html).

Patel, J.A., F.B.H. Nielsen, A. A. Badiani, S. Assi, V.A. Unadkat, B. Patel, and H. Wardle. 2020. "Poverty, Inequality and COVID-19: The Forgotten Vulnerable. Public Health 183:110. 
Peñaranda, Aylin. 2020. "La Policía levantó al menos 420 cuerpos en calles, vehículos y domicilios en cinco días." $\mathrm{La}$ Razon, 21 de Julio. (https://www.la-razon.com/ ciudades/2020/07/21/la-policia-levanto-al-menos-420cuerpos-en-calles-vehiculos-y-domicilios-en-cinco-dias/).

Peredo, Nelson. 2020.). "Beni: fallas estructurales y miles de automedicados desbordan la crisis." Los Tiempos, 27 de Mayo. (https://www.lostiempos.com/actualidad/ pais/20200527/beni-fallas-estructurales-milesautomedicados-desbordan-crisis).

Putnam, Robert D., Robert Leonardi, and Rafaella Y. Nanetti. 1993. Making Democracy Work: Civic Traditions in Modern Italy. Princeton, NJ: Princeton University Press.

Redacción Central, Bolivia en tus Manos (2019, 19 de Julio). Estudio revela que cada vez más usuarios de iPhone cambian sus teléfonos por dispositivos Android. Bolivia en tus manos: Tecnología. https://www. boliviaentusmanos.com/noticias/tecnologia/339548/ estudio-revela-que-cada-vez-mas-usuarios-de-iphonecambian-sus-telefonos-por-dispositivos-android.html

Sani, Giacomo, and Giovanni Sartori. 1983. "Polarization, Fragmentation and Competition in Western Democracies." Western European Party Systems, 307-340.

Scholtz, John T., and Mark Lubell. 1998. "Trust and Taxpaying: Testing the Heuristic Approach to Collective Action." American Journal of Political Science 42(2): 398-417.

Seligson, Mitchell A. 2006. "The Measurement and Impact of Corruption Victimization: Survey Evidence from Latin America." World Development 34(2): 381-404.

SERECI (Civil Registry Service or Servicio de Registro Civico). 2020. https://www.oep.org.bo/registro-civico/
Svolik, Milan W. 2013. "Learning to Love Democracy: Electoral Accountability and the Success of Democracy. American Journal of Political Science 57(3): 685-702.

Trigo, María Silvia, Anatoly Kurmaneav, and Allison McCann. 2020. "As Politicians Clashed, Bolivia's Pandemic Death Rate Soared." New York Times, August 22. (https://www.nytimes.com/2020/08/22/ world/americas/virus-bolivia.html?searchResult Position=1).

Trigo, María Silvia, Anatoly Kurmaneav, and José María León Cabrera. 2020. "With Official's Backing, Dubious Virus Remedies Surge in Latin America." New York Times, July 23. (https://www.nytimes.com/ 2020/07/23/world/americas/chlorine-coronavirusbolivia-latin-america.html).

Vergara, Alberto (2018). La danza hostil: poderes subnacionales y Estado central en Bolivia y Perú (1952-2012). Instituto de Estudios Peruanos.

World Bank. 2020. World Development Indicators. GNI per capita, Atlas method. (htttps://data.worldbank.org/ indicator/NY.GNP.PCAP.CD?locations=BO).

Zegada, Maria Teresa. 2020. "Crisis, más allá de lo evidente.” La Razon, 9 de Septiembre. (https://www.larazon.com/politico/2020/09/09/crisis-mas-alla-delo-evidente/).

Zegada, Maria Teresa., Erika Brockmann Quiroga. 2016. "Autonomías departamentales en Bolivia: hacia la consolidación de un sistema político multinivel." Revista Uruguaya de Ciencia Política 25(1): 110-30.

Zoraster, Richard M. 2006. "Barriers to Disaster Coordination: Health Sector Coordination in Banda Aceh Following the South Asia Tsunami." Prehospital and Disaster Medicine 21(1): s13-18. 